\title{
NUTRITIONAL HABITS AND KNOWLEDGE ABOUT FOOD AND NUTRITION AMONG PHYSICAL EDUCATION STUDENTS DEPENDING ON THEIR LEVEL OF HIGHER EDUCATION AND PHYSICAL ACTIVITY
}

\author{
HELENA POPŁAWSKA ${ }^{1 A}$, AGNIESZKA DMITRUK ${ }^{1 \mathrm{~A}}$, IZABELA KUNICKA ${ }^{2}$, \\ ALEKSANDRA DĘBOWSKA ${ }^{1 \mathrm{~B}}$, WOJCIECH HOŁUB ${ }^{3}$ \\ Józef Piłsudski University of Physical Education in Warsaw, Faculty of Physical Education and Sport \\ in Biała Podlaska, Chair of Natural Sciences ${ }^{a}$, Chair of Physical Education ${ }^{b}$, Biała Podlaska, Poland \\ ${ }^{2}$ Pope John Paul II State School of Higher Education in Biała Podlaska, Section of Student Internships \\ and Career Office, Biała Podlaska, Poland \\ 3 Józef Pitsudski University of Physical Education in Warsaw, Faculty of Health and Tourism in Biała Podlaska, \\ Chair of Health Sciences, Biała Podlaska, Poland
}

Mailing address: Agnieszka Dmitruk, Józef Piłsudski University of Physical Education in Warsaw, Faculty of Physical Education and Sport in Biała Podlaska, 2 Akademicka Street, 21-500 Biała Podlaska, tel.: +48 83 3428738, fax: +48 83 3428800, e-mail: agnieszka.dmitruk@awf-bp.edu.pl

\begin{abstract}
Introduction. Nutritional habits as well as views on food and nutrition are determined by a number of factors regarding an individual, social group, or population. The aim of the study was to determine differences in nutritional habits and knowledge about food and nutrition in physical education (PE) students depending on their level of higher education and physical activity. Material and methods. The study included 207 first-year and last-year students of physical education from the Faculty of Physical Education and Sport in Biala Podlaska. The eating habits of the study participants and their knowledge about food and nutrition were evaluated using a questionnaire developed by Gawęcki, while physical activity was assessed with the International Physical Activity Questionnaire (IPAQ - short version). Statistical significance of differences between groups distinguished on the basis of the students' level of higher education and physical activity was analysed with Student's t-test or the $\chi^{2}$ test. Results and conclusions. Regardless of the level of higher education and physical activity, the students examined most often demonstrated low intensity of nutritional behaviours that were either beneficial or detrimental to health, which means that they did not choose products with a potentially beneficial influence on their health very often, but, at the same time, they limited their consumption of unhealthy products. However, the comparison of students in terms of their level of education revealed that last-year students consumed poultry, fruit, and vegetables more often, whereas first-year students consumed white bread, butter, cold meat, cheese, and sweets more frequently. Women with a high level of physical activity consumed healthy foods more often, while men exhibited such a tendency in the case of dairy products only. Most students demonstrated sufficient knowledge about food and nutrition, and it was noted that their university studies increased their level of knowledge in this area.
\end{abstract}

Key words: diet, physical activity, students

\section{Introduction}

Lifestyle, including health behaviours, is a factor that exerts a significant influence on a person's health status. Health behaviours are any health-related habits, attitudes, and activities as well as values accepted by members of a given society. These include proper nutrition, regular physical activity, adequate sleep duration, avoiding drugs, and being able to cope with stress [1]. Proper nutrition and appropriate physical activity levels are the most substantial of these factors [2].

University students are a social group that is important for the future of every country. Studying at university is a transition period between the carefreeness of youth and the demands of adult life. During this period, a traditional home diet is often remodelled as a result of acquiring knowledge while studying, observing peers' diets, and gaining information from mass media. The fact that both studies and social life take up much time means that students usually eat on an irregular basis and consume more and more fast foods which are difficult to digest and whose nutritional values are not properly balanced [3, 4]. Not getting enough sleep, eating in a hurry, and consuming products of low nutritional value may lead to a deficiency in vitamins and mineral nutrients [5]. Diet is of particular significance in the case of physical education (PE) students, who are much more physically active than their counterparts from other university courses [6].

The aim of the study was to determine differences in nutritional habits and knowledge about food and nutrition in PE students depending on the stage of higher education and physical activity level. 


\section{Material and methods}

The study included 207 PE students from the Faculty of Physical Education and Sport in Biala Podlaska (part of the University of Physical Education in Warsaw). The study group consisted of first-year Bachelor's students $(\mathrm{n}=141)$ and last-year Master's students (students in the second year of second-degree studies; $n=66$ ). Male students constituted the majority of the study participants (72.34\% of first-year students and $65.15 \%$ of last-year students were male). An attempt was made at including all first- and last-year students in the research; however, some did not agree to participate in the study (17.2\%).

The subjects' nutritional habits and knowledge about food and nutrition were assessed with the KomPAN questionnaire [7] using the recommended procedure of nutritional data processing [8]. The quality of the diet was evaluated using two indices: the Healthy Diet Index (HDI-10) and the Unhealthy Diet Index (UDI-14). The values of the indices were calculated based on the sum of the frequency of consuming the selected groups of 10 and 14 food products for HDI and UDI, respectively. The groups of food items included in HDI-10 and UDI-14 are presented in Tables 1 and 2. According to the methodology of the KomPAN questionnaire [7], the frequency of consuming each group of food products listed in Tables 1 and 2 is presented in the form of times per day (Tab. 3). Afterwards, these values are summed for each participant, separately for the healthy and unhealthy diet. The interpretation of the obtained values is presented in Table 4. The use of the values of times per day included in this table makes it possible to determine the intensity (low, moderate, or high) of healthy and unhealthy eating habits for each study participant.

In order to compare the frequency of consuming particular products included in HDI-10 and UDI-14 between first-year and last-year students, the numbers of times that each of the analysed products was eaten were summed for these groups, separately for women and men.

The above-mentioned questionnaire was used to assess students' knowledge about food and nutrition. One point was given for every correct answer, while no points were awarded if an incorrect answer or a "difficult to say" response was provided. Based on the sum of points scored by each participant,

Table 1. KomPAN questionnaire list of food products from Healthy Diet Index (HDI-10) with potentially beneficial health effects [8]

\begin{tabular}{|c|l|}
\hline No. & \multicolumn{1}{|c|}{$\begin{array}{l}\text { Healthy Diet Index (HDI-10) and its food products in KomPAN } \\
\text { questionnaire }\end{array}$} \\
\hline 1 & wholemeal bread \\
\hline 2 & wholemeal pasta, buckwheat, oatmeal, or other whole groats \\
\hline 3 & milk (including flavoured milk, cocoa, and milk coffee) \\
\hline 4 & fermented milk drinks, e.g. yoghurt or kefir (natural or flavoured) \\
\hline 5 & $\begin{array}{l}\text { cottage cheese (including smooth cottage cheese and cottage } \\
\text { cheese desserts) }\end{array}$ \\
\hline 6 & white meat dishes, e.g. chicken, turkey, or rabbit dishes \\
\hline 7 & fish \\
\hline 8 & legume dishes, e.g. bean, pea, soya, or lentil dishes \\
\hline 9 & fruit \\
\hline 10 & vegetables \\
\hline \multicolumn{2}{|c|}{ HDI-10 = sum of consumption frequency of 10 groups of food products } \\
(times/day; range: 0 -20)
\end{tabular}

nutrition-related knowledge levels were determined (good: 1725 pts; sufficient: 9-16 pts; and insufficient: 0-8 pts).

The physical activity of the subjects was evaluated using the International Physical Activity Questionnaire (IPAQ - short version). The questionnaire includes 7 questions concerning all types of physical activity associated with everyday life, work, and leisure. Each type of physical activity (walking, high-intensity activity, and moderate-intensity activity) was expressed in MET minutes/week. The coefficient of a given activity was multiplied by the number of days per week on which this activity was

Table 2. KomPAN questionnaire list of food products from Unhealthy Diet Index (UDI-14) with potentially detrimental health effects [8]

\begin{tabular}{|c|c|}
\hline No. & $\begin{array}{c}\text { Unhealthy Diet Index (UDI-14) and its food products in KomPAN } \\
\text { questionnaire }\end{array}$ \\
\hline 1 & $\begin{array}{l}\text { white bread, e.g. wheat bread, rye bread, wheat-rye bread, toasts, } \\
\text { rolls, or croissants }\end{array}$ \\
\hline 2 & white rice, pasta, or groats, e.g. semolina or couscous \\
\hline 3 & fast foods, e.g. chips, hamburgers, pizza, or hot dogs \\
\hline 4 & fried meat- or flour-based dishes \\
\hline 5 & butter eaten with bread or dishes, or used for frying, baking, etc. \\
\hline 6 & lard eaten with bread or dishes, or used for frying, baking, etc. \\
\hline 7 & cheese (including processed cheese and blue cheese) \\
\hline 8 & cold meat, sausages, or frankfurters \\
\hline 9 & $\begin{array}{l}\text { red meat dishes, e.g. pork, beef, veal, mutton, lamb, or venison } \\
\text { dishes }\end{array}$ \\
\hline 10 & $\begin{array}{l}\text { sweets and confectionery, e.g. biscuits, cakes, chocolate bars, } \\
\text { muesli bars, and others }\end{array}$ \\
\hline 11 & canned meat \\
\hline 12 & $\begin{array}{l}\text { sweetened carbonated drinks, e.g. Coca-Cola, Pepsi, Sprite, Fanta, } \\
\text { orangeade, or lemonade }\end{array}$ \\
\hline 13 & $\begin{array}{l}\text { energy drinks, e.g. } 2 \text { KC, Black Horse, Red Bull, Burn, Shot, or } \\
\text { others }\end{array}$ \\
\hline 14 & alcoholic beverages \\
\hline \multicolumn{2}{|r|}{$\begin{array}{l}\text { UDI-14 = sum of consumption frequency of } 14 \text { groups of food products } \\
\text { (times/day; range: } 0-28 \text { ) }\end{array}$} \\
\hline
\end{tabular}

Table 3. Recommended values for frequency of consuming food items in KomPAN questionnaire [8]

\begin{tabular}{|c|c|}
\hline Consumption frequency & Daily frequency (times/day) \\
\hline Never & 0 \\
\hline $1-3$ times a month & 0.06 \\
\hline Once a week & 0.14 \\
\hline Several times a week & 0.5 \\
\hline Once a day & 1 \\
\hline Several times a day & 2 \\
\hline
\end{tabular}

Table 4. Recommended HDI-10 and UDI-14 interpretation method for KomPAN questionnaire [8]

\begin{tabular}{|c|c|c|}
\hline \multirow{2}{*}{$\begin{array}{c}\text { Nutritional feature } \\
\text { intensity }\end{array}$} & \multicolumn{2}{|c|}{ Range (times/day) } \\
\cline { 2 - 3 } & $\begin{array}{c}\text { Healthy Diet Index, } \\
\text { HDI-10 }\end{array}$ & $\begin{array}{c}\text { Unhealthy Diet Index, } \\
\text { UDI-14 }\end{array}$ \\
\hline Low & $0-6.66$ & $0-9.33$ \\
\hline Moderate & $6.67-13.33$ & $9.34-18.66$ \\
\hline High & $13.34-20$ & $18.67-28$ \\
\hline
\end{tabular}


performed and its duration (minutes/day). On the basis of the results obtained, the students were classified into groups with particular levels of physical activity. The first one was persons with high-intensity activity, that is performing 3 or more days of intensive physical activity with a total of at least 1,500 MET $\mathrm{min} /$ week or 7 or more days of one of the combinations (walking, high-intensity activity, and moderate-intensity activity) exceeding 3,000 MET min/week. The second group was characterised by sufficient activity, with 3 or more days of intensive physical effort for at least 20 minutes per day, 5 or more days of moderate effort or walking for at least 30 minutes per day, or 5 or more days of one of the combinations (walking, high-intensity activity, and moderate-intensity activity) exceeding 600 MET $\mathrm{min} /$ week. The last group was to include persons having insufficient activity, who did not perform any physical activity or did not meet the requirements for the sufficient or high levels according to the IPAQ methodology [9]. Due to the fact that only one man demonstrated an insufficient level of physical activity, two groups, with sufficient and high-intensity physical activity, were taken into account in further analysis. The results of the person with an insufficient level of physical activity were not included in the analysis.

Student's t-test was employed to assess the significance of differences in the frequency of consuming food items from HDI-10 and UDI-14 by women and men depending on the stage of higher education (first or last year) and physical activity level (high or sufficient). Differences in nutrition-related knowledge between the groups were evaluated with the $\chi^{2}$ test. The calculations were performed using STATISTICA v. 12 software [10].

\section{Results}

Regardless of the level of higher education, the students examined most often demonstrated low intensity of nutritional behaviours that were either beneficial or detrimental to health. Healthy moderate-intensity habits were noted in 11 to $22 \%$ of the study participants, while unhealthy moderate-intensity habits were found in first-year students only. Healthy high-intensity habits were only observed in one first-year student, whereas last-year students did not manifest such behaviours at all (Tab. 5). The present study also focused on the frequency of consuming food items (times/day) from HDI-10 and UDI-14. The analysis of differences between the group of last-year female students and the group of first-year female students regarding HDI-10 revealed that the former group consumed fruit and vegetables, poultry, milk, as well as whole groats and wholemeal pasta more often, whereas the latter group had wholemeal bread as well as yoghurt and kefir more frequently. In the case of UDI-14, lastyear female students consumed white rice and pasta as well as lard more often, while their first-year peers had white bread, butter, cheese, cold meat, sweets and energy drinks more often. The mean HDI-10 value in both groups was low and did not exceed 5.6 times/day (in the range from 0 to 20); however, this value was slightly higher in last-year female students. The mean UDI-14 value also fell within the range of low-intensity eating habits (below 5.0 times/day in the range from 0 to 28). It was noted that first-year students obtained a slightly higher value of this index, which means that they chose products which had a detrimental influence on health more often (Fig. 1 and 2). As for male subjects, differences in the frequency of consuming food items from HDI-10 and UDI-14 between first- and lastyear students were greater and more often significant than in the case of female study participants. The biggest differences regarding HDI-10 between first-year male students and their
Table 5. Intensity of healthy and unhealthy eating habits in females and males depending on level of higher education

\begin{tabular}{|c|c|c|c|c|c|c|c|c|c|c|c|c|}
\hline \multirow{3}{*}{ Gender } & \multicolumn{6}{|c|}{ Healthy habits } & \multicolumn{6}{|c|}{ Unhealthy habits } \\
\hline & \multicolumn{2}{|c|}{ Low } & \multicolumn{2}{|c|}{ Moderate } & \multicolumn{2}{|c|}{ High } & \multicolumn{2}{|c|}{ Low } & \multicolumn{2}{|c|}{ Moderate } & \multicolumn{2}{|c|}{ High } \\
\hline & $n$ & $\%$ & $\mathrm{n}$ & $\%$ & $n$ & $\%$ & $\mathrm{n}$ & $\%$ & $n$ & $\%$ & $n$ & $\%$ \\
\hline \multicolumn{13}{|c|}{ First year } \\
\hline $\mathrm{F}$ & 34 & 87.18 & 5 & 12.82 & 0 & 0.00 & 35 & 89.74 & 4 & 10.26 & 0 & 0.00 \\
\hline$M$ & 79 & 77.45 & 22 & 21.57 & 1 & 0.98 & 92 & 90.20 & 10 & 9.80 & 0 & 0.00 \\
\hline \multicolumn{13}{|c|}{ Last year } \\
\hline $\mathrm{F}$ & 18 & 78.26 & 5 & 21.74 & 0 & 0.00 & 23 & 100.00 & 0 & 0.00 & 0 & 0.00 \\
\hline M & 38 & 88.37 & 5 & 11.63 & 0 & 0.00 & 43 & 100.00 & 0 & 0.00 & 0 & 0.00 \\
\hline
\end{tabular}

$\mathrm{F}$ - females, M - males.

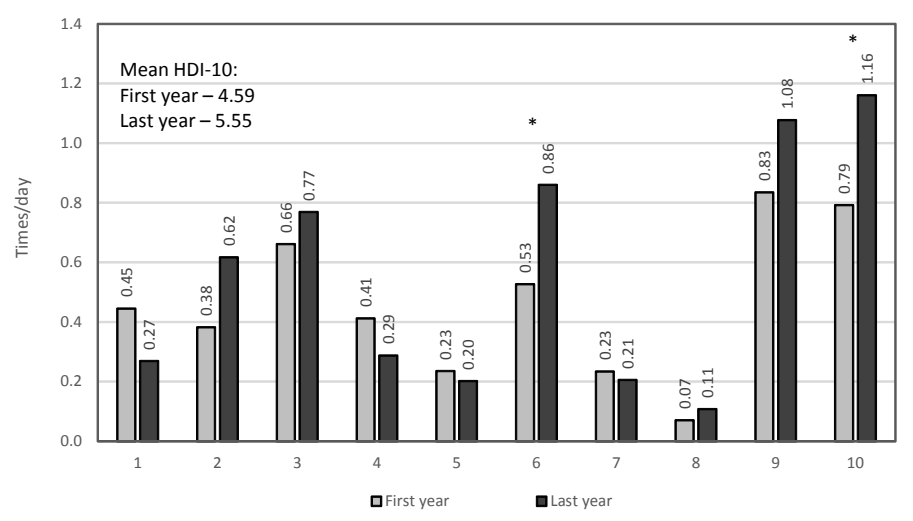

* = significant difference at the level of $\mathrm{p} \leq 0.05$ (Student's t- test).

1. wholemeal bread; 2 . wholemeal pasta, buckwheat, oatmeal, or other whole groats; 3. milk (including flavoured milk, cocoa, and milk coffee); 4. fermented milk drinks, e.g. yoghurt or kefir (natural or flavoured); 5. cottage cheese (including smooth cottage cheese and cottage cheese desserts); 6 . white meat dishes, e.g. chicken, turkey, or rabbit dishes; 7. fish; 8. legume dishes, e.g. bean, pea, soya, or lentil dishes; 9. fruit; 10. vegetables

Figure 1. Frequency of consuming food items from HDI-10 in females depending on level of higher education

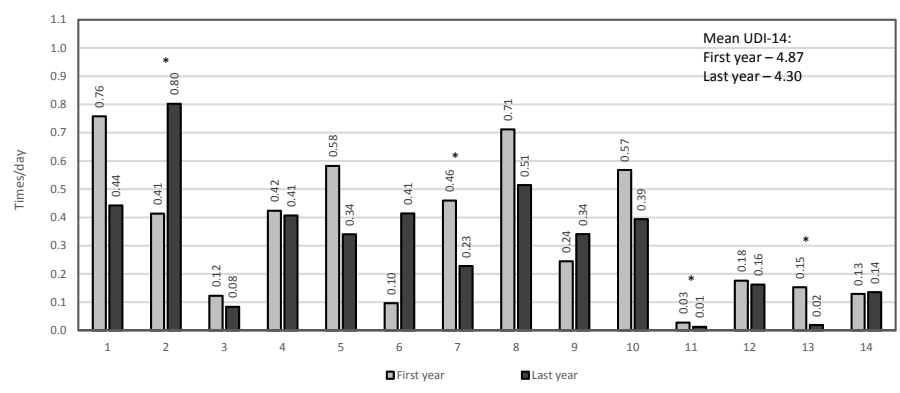

* = significant difference at the level of $\mathrm{p} \leq 0.05$ (Student's t- test).

1. white bread, e.g. wheat bread, rye bread, wheat-rye bread, toasts, rolls, or croissants; 2. white rice, pasta, or groats, e.g. semolina or couscous; 3 . fast foods, e.g. chips, hamburgers, pizza, or hot dogs; 4 . fried meat- or flour-based dishes; 5 . butter eaten with bread or dishes, or used for frying, baking, etc.; 6 . lard eaten with bread or dishes, or used for frying, baking, etc.; 7. cheese (including processed cheese and blue cheese); 8. cold meat, sausages, or frankfurters; 9. red meat dishes, e.g. pork, beef, veal, mutton, lamb, or venison dishes; 10 . sweets and confectionery, e.g. biscuits, cakes, chocolate bars, muesli bars, and others; 11. canned meat; 12. sweetened carbonated drinks, e.g. Coca-Cola, Pepsi, Sprite, Fanta, orangeade, or lemonade; 13. energy drinks, e.g. 2 KC, Black Horse, Red Bull, Burn, Shot, or others; 14 . alcoholic beverages.

Figure 2. Frequency of consuming food items from UHDI-14 in females depending on level of higher education 
last-year peers were noted in the frequency of consuming milk, fermented milk drinks, and cottage cheese (first-year students consumed them more often) as well as in the frequency of consuming whole groats, wholemeal pasta, poultry, and vegetables (consumption was greater in last-year students). The analysis of the frequency of consuming food items from UDI-14 showed that these products were more often consumed by first-year students. This concerned the majority of products from this group except for white rice and pasta, fried meat- or flour-based dishes, as well as lard eaten with bread or dishes or used for frying or baking. On the basis of the mean healthy and unhealthy diet indices, it may be noted that there were slight differences in HDI-10 between first-year and last-year male students, while

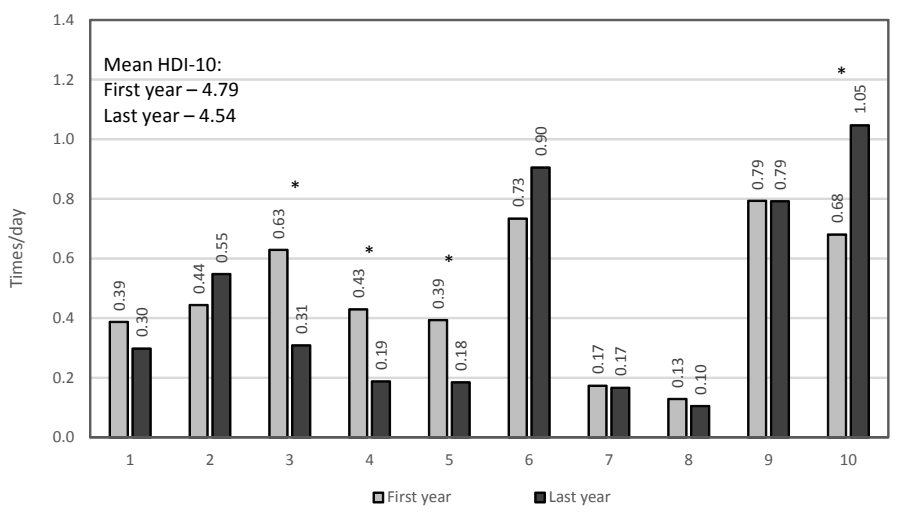

* = significant difference at the level of $\mathrm{p} \leq 0.05$ (Student's t- test).

1. wholemeal bread; 2 . wholemeal pasta, buckwheat, oatmeal, or other whole groats; 3. milk (including flavoured milk, cocoa, and milk coffee); 4. fermented milk drinks, e.g. yoghurt or kefir (natural or flavoured); 5. cottage cheese (including smooth cottage cheese and cottage cheese desserts); 6 . white meat dishes, e.g. chicken, turkey, or rabbit dishes; 7. fish; 8. legume dishes, e.g. bean, pea, soya, or lentil dishes; 9. fruit; 10. vegetables.

Figure 3. Frequency of consuming food items from HDI-10 in males depending on level of higher education

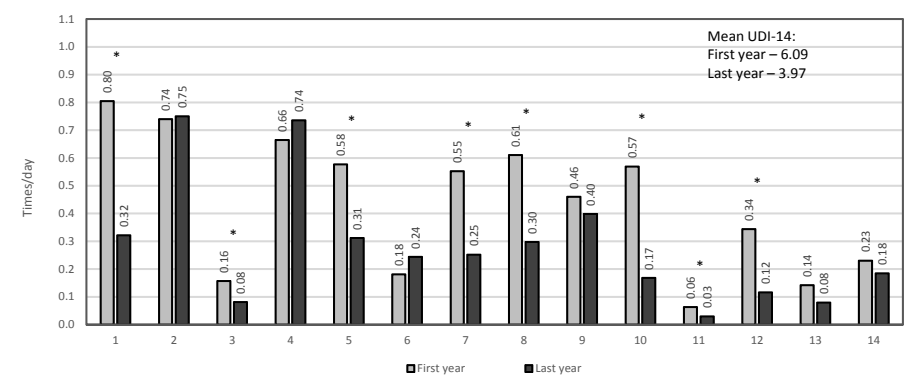

* = significant difference at the level of $\mathrm{p} \leq 0.05$ (Student's t- test).

1. white bread, e.g. wheat bread, rye bread, wheat-rye bread, toasts, rolls, or croissants;

2. white rice, pasta, or groats, e.g. semolina or couscous; 3 . fast foods, e.g. chips,

hamburgers, pizza, or hot dogs; 4 . fried meat- or flour-based dishes; 5 . butter eaten with

bread or dishes, or used for frying, baking, etc.; 6 . lard eaten with bread or dishes, or used for frying, baking, etc.; 7. cheese (including processed cheese and blue cheese); 8 . cold meat, sausages, or frankfurters; 9. red meat dishes, e.g. pork, beef, veal, mutton, lamb, or venison dishes; 10 . sweets and confectionery, e.g. biscuits, cakes, chocolate bars, muesli bars, and others; 11. canned meat; 12. sweetened carbonated drinks, e.g. Coca-Cola, Pepsi, Sprite, Fanta, orangeade, or lemonade; 13. energy drinks, e.g. 2 KC, Black Horse, Red Bull, Burn, Shot, or others; 14. alcoholic beverages.

Figure 4. Frequency of consuming food items from UDI-14 in males depending on level of higher education for UDI-14, similarly as was the case with women, more frequent consumption of potentially unhealthy products was noted in first-year male students (Fig. 3 and 4).

The study also focused on the subjects' nutritional behaviours depending on their physical activity levels. The majority of female and male respondents exhibited high levels of physical activity (77.42\% and $91.03 \%$, respectively). The remaining study participants had sufficient levels of physical activity. Regardless of the level of higher education and physical activity, the students most often demonstrated low intensity of nutritional behaviours that were either beneficial or detrimental to health, which means that they did not choose products with a potentially beneficial influence on their health very often, but

Table 6. Intensity of healthy and unhealthy eating habits in females depending on physical activity level

\begin{tabular}{|c|c|c|c|c|c|c|c|c|c|c|c|c|}
\hline \multirow{3}{*}{$\begin{array}{c}\text { Activity } \\
\text { level }\end{array}$} & \multicolumn{6}{|c|}{ Healthy habits } & \multicolumn{6}{|c|}{ Unhealthy habits } \\
\hline & \multicolumn{2}{|c|}{ Low } & \multicolumn{2}{|c|}{ Moderate } & \multicolumn{2}{|c|}{ High } & \multicolumn{2}{|c|}{ Low } & \multicolumn{2}{|c|}{ Moderate } & \multicolumn{2}{|c|}{ High } \\
\hline & $n$ & $\%$ & $\mathrm{n}$ & $\%$ & & $\%$ & $\mathrm{n}$ & $\%$ & $n$ & $\%$ & $n$ & $\%$ \\
\hline High & 39 & 81.25 & 9 & 18.75 & 0 & 0.00 & 45 & 93.75 & 3 & 6.25 & 0 & 0.00 \\
\hline Sufficient & 13 & 92.86 & 1 & 7.14 & 0 & 0.00 & 13 & 92.86 & 1 & 7.14 & 0 & 0.00 \\
\hline Insufficient & 0 & 0.00 & 0 & 0.00 & 0 & 0.00 & 0 & 0.00 & 10 & 0.00 & 0 & 0.00 \\
\hline
\end{tabular}

Table 7. Intensity of healthy and unhealthy eating habits in males depending on physical activity level

\begin{tabular}{|c|c|c|c|c|c|c|c|c|c|c|c|c|}
\hline \multirow{2}{*}{$\begin{array}{c}\text { Activ- } \\
\text { ity } \\
\text { level }\end{array}$} & \multicolumn{4}{|c|}{ Low } & \multicolumn{1}{|c|}{ Moderate } & \multicolumn{5}{|c|}{ High } & \multicolumn{3}{|c|}{ Low } & \multicolumn{2}{|c|}{ Moderate } & \multicolumn{2}{|c|}{ High } \\
\cline { 2 - 13 } & $\mathrm{n}$ & $\%$ & $\mathrm{n}$ & $\%$ & $\mathrm{n}$ & $\%$ & $\mathrm{n}$ & $\%$ & $\mathrm{n}$ & $\%$ & $\mathrm{n}$ & $\%$ \\
\hline High & 107 & 81.06 & 24 & 18.18 & 1 & 0.76 & 122 & 92.42 & 10 & 7.58 & 0 & 0.00 \\
\hline $\begin{array}{c}\text { Suffi- } \\
\text { cient }\end{array}$ & 9 & 75.00 & 3 & 25.00 & 0 & 0.00 & 12 & 100.00 & 0 & 0.00 & 0 & 0.00 \\
\hline $\begin{array}{l}\text { Insuf- } \\
\text { ficient }\end{array}$ & 1 & 100.00 & 0 & 0.00 & 0 & 0.00 & 1 & 100.00 & 0 & 0.00 & 0 & 0.00 \\
\hline
\end{tabular}

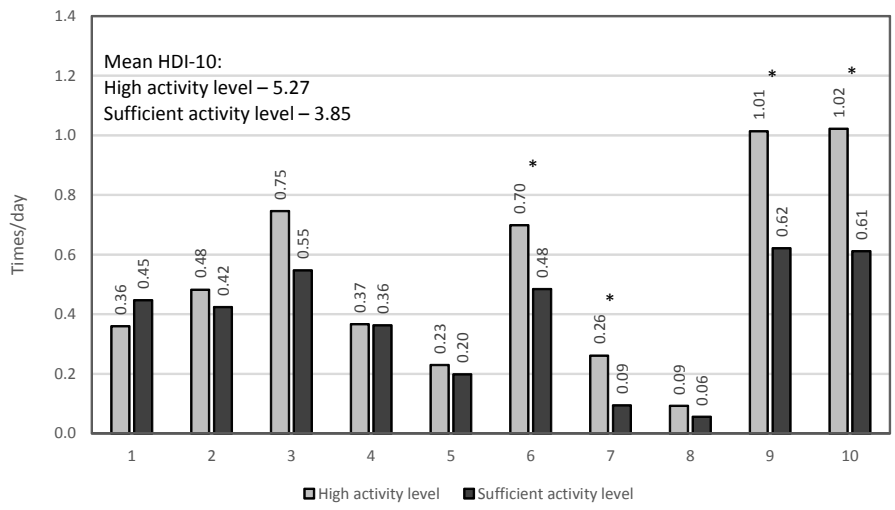

* = significant difference at the level of $\mathrm{p} \leq 0.05$ (Student's t- test).

1. wholemeal bread; 2 . wholemeal pasta, buckwheat, oatmeal, or other whole groats; 3. milk (including flavoured milk, cocoa, and milk coffee); 4. fermented milk drinks, e.g. yoghurt or kefir (natural or flavoured); 5. cottage cheese (including smooth cottage cheese and cottage cheese desserts); 6 . white meat dishes, e.g. chicken, turkey, or rabbit dishes; 7. fish; 8. legume dishes, e.g. bean, pea, soya or lentil dishes; 9. fruit; 10. vegetables.

Figure 5. Frequency of consuming food items from HDI-10 in females depending on level of physical activity 


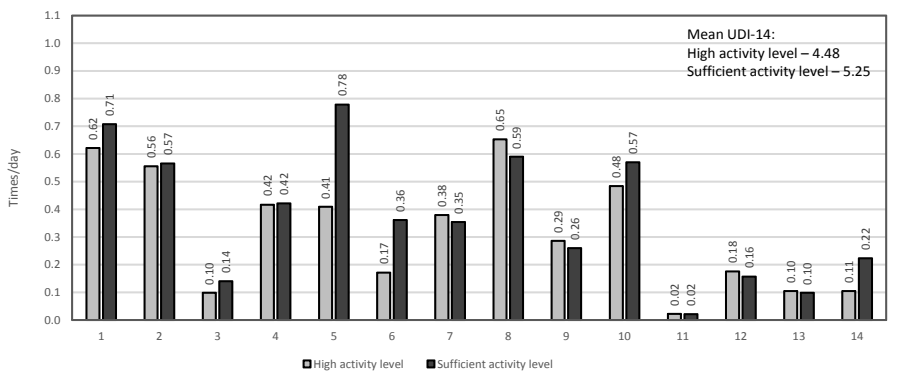

1. white bread, e.g. wheat bread, rye bread, wheat-rye bread, toasts, rolls, or croissants; 2. white rice, pasta, or groats, e.g. semolina or couscous; 3 . fast foods, e.g. chips, hamburgers, pizza, or hot dogs; 4 . fried meat- or flour-based dishes; 5 . butter eaten with bread or dishes, or used for frying, baking, etc.; 6 . lard eaten with bread or dishes, or used for frying, baking, etc.; 7. cheese (including processed cheese and blue cheese); 8 . cold meat, sausages, or frankfurters; 9. red meat dishes, e.g. pork, beef, veal, mutton, lamb, or venison dishes; 10 . sweets and confectionery, e.g. biscuits, cakes, chocolate bars, muesli bars, and others; 11. canned meat; 12. sweetened carbonated drinks, e.g. Coca-Cola, Pepsi, Sprite, Fanta, orangeade, or lemonade; 13. energy drinks, e.g. 2 KC, Black Horse, Red Bull, Burn, Shot, or others; 14. alcoholic beverages.

Figure 6. Frequency of consuming food items from UDI-14 in females depending on level of physical activity

at the same time they limited their consumption of unhealthy products (Tab. 6 and 7). In females, the greatest significant differences occurred in HDI-10 and regarded poultry, fruit, and vegetables - these items were more often consumed by students demonstrating high levels of physical activity. In males, significant differences were found in the consumption of milk and fermented milk drinks in HDI-10 as well as cheese and sweets in UDI-14. These food products were more often consumed by students with high levels of physical activity. During the analysis of the mean values of HDI-10 and UDI-14, it was noted that women with high levels of physical activity chose healthy products more often and potentially unhealthy products less frequently. Among men, slight differences between HDI-10 and UDI-14 were noted depending on physical activity (Fig. 5-8).

Based on the findings of the research carried out with the use of the KomPAN questionnaire, we also determined the students' level of knowledge about food and nutrition. Regardless of the stage of higher education and physical activity levels, most participants had sufficient knowledge in this respect. It was also observed that the percentage of women and men with insufficient knowledge was significantly higher among first-year students, while the percentage of individuals with good knowledge was significantly higher among last-year students (Tab. 8).

Table 8. Level of knowledge about nutrition in females and males depending on level of higher education

\begin{tabular}{|c|c|c|c|c|c|c|c|c|}
\hline \multirow{2}{*}{$\begin{array}{c}\text { Level of } \\
\text { knowledge }\end{array}$} & \multicolumn{3}{|c|}{ Females } & \multicolumn{4}{c|}{ Males } \\
\cline { 2 - 9 } & First year & \multicolumn{2}{|c|}{ Last year } & \multicolumn{2}{c|}{ First year } & \multicolumn{2}{c|}{ Last year } \\
\cline { 2 - 9 } & $\mathrm{n}$ & $\%$ & $\mathrm{n}$ & $\%$ & $\mathrm{n}$ & $\%$ & $\mathrm{n}$ & $\%$ \\
\hline Insufficient & 9 & 23.08 & 2 & 8.70 & 18 & 17.65 & 2 & 4.65 \\
\hline Sufficient & 28 & 71.79 & 18 & 78.26 & 79 & 77.45 & 36 & 83.72 \\
\hline Good & 2 & 5.13 & 3 & 13.04 & 5 & 4.90 & 5 & 11.63 \\
\hline$X^{2}$ test & \multicolumn{3}{|c|}{$9.920, p=0.007^{*}$} & \multicolumn{3}{c|}{$10.530, p=0.005^{*}$} \\
\hline
\end{tabular}

* $=$ significant difference at the level of $\mathrm{p} \leq 0.05$.

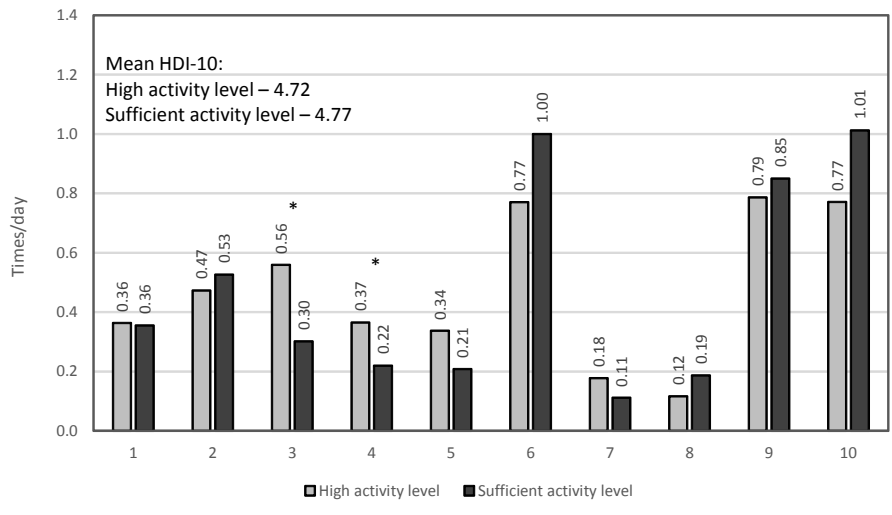

* = significant difference at the level of $\mathrm{p} \leq 0.05$ (Student's t- test).

1. wholemeal bread; 2 . wholemeal pasta, buckwheat, oatmeal, or other whole groats; 3. milk (including flavoured milk, cocoa, and milk coffee); 4. fermented milk drinks, e.g. yoghurt or kefir (natural or flavoured); 5. cottage cheese (including smooth cottage cheese and cottage cheese desserts); 6 . white meat dishes, e.g. chicken, turkey, or rabbit dishes; 7. fish; 8. legume dishes, e.g. bean, pea, soya or lentil dishes; 9. fruit; 10. vegetables.

Figure 7. Frequency of consuming food items from HDI-10 in males depending on level of physical activity

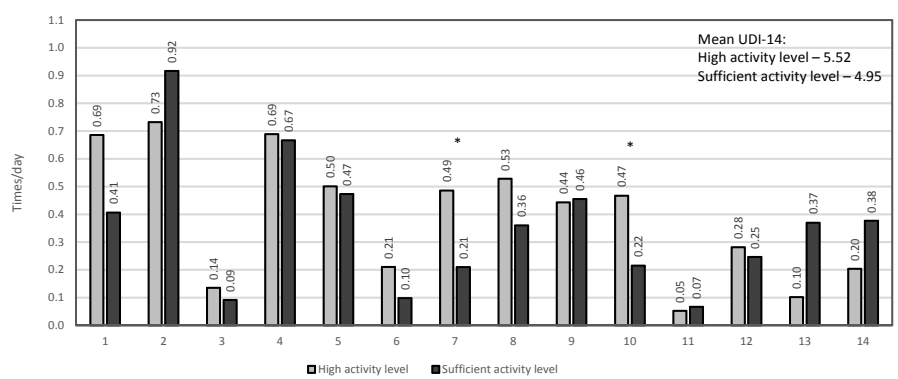

* = significant difference at the level of $\mathrm{p} \leq 0.05$ (Student's t- test).

1. white bread, e.g. wheat bread, rye bread, wheat-rye bread, toasts, rolls, or croissants; 2. white rice, pasta, or groats, e.g. semolina or couscous; 3 . fast foods, e.g. chips, hamburgers, pizza, or hot dogs; 4 . fried meat- or flour-based dishes; 5 . butter eaten with bread or dishes, or used for frying, baking, etc.; 6. lard eaten with bread or dishes, or used for frying, baking, etc.; 7. cheese (including processed cheese and blue cheese); 8. cold meat, sausages, or frankfurters; 9. red meat dishes, e.g. pork, beef, veal, mutton, lamb, or venison dishes; 10 . sweets and confectionery, e.g. biscuits, cakes, chocolate bars, muesli bars, and others; 11. canned meat; 12. sweetened carbonated drinks, e.g. Coca-Cola, Pepsi, Sprite, Fanta, orangeade, or lemonade; 13. energy drinks, e.g. 2 KC, Black Horse, Red Bull, Burn, Shot, or others; 14 . alcoholic beverages.

Figure 8. Frequency of consuming food items from UDI-14 in males depending on level of physical activity

Table 9. Level of knowledge about nutrition in females and males depending on physical activity level

\begin{tabular}{|c|c|c|c|c|c|c|c|c|}
\hline \multirow{2}{*}{$\begin{array}{c}\text { Level of } \\
\text { knowledge }\end{array}$} & \multicolumn{4}{|c|}{$\begin{array}{c}\text { Females } \\
\text { High activity } \\
\text { level }\end{array}$} & $\begin{array}{c}\text { Sufficient } \\
\text { activity level }\end{array}$ & \multicolumn{4}{c|}{$\begin{array}{c}\text { High activity } \\
\text { level }\end{array}$} & $\begin{array}{c}\text { Sufficient } \\
\text { activity level }\end{array}$ \\
\cline { 2 - 9 } & $\mathrm{n}$ & $\%$ & $\mathrm{n}$ & $\%$ & $\mathrm{n}$ & $\%$ & $\mathrm{n}$ & $\%$ \\
\hline Insufficient & 6 & 12.50 & 5 & 35.71 & 19 & 14.39 & 1 & 8.33 \\
\hline Sufficient & 38 & 79.17 & 8 & 57.14 & 105 & 79.55 & 9 & 75.00 \\
\hline Good & 4 & 8.33 & 1 & 7.14 & 8 & 6.06 & 2 & 16.67 \\
\hline$X^{2}$ test & \multicolumn{3}{|c|}{$14.421, p=0.001^{*}$} & \multicolumn{5}{c|}{$7.058, p=0.029^{*}$} \\
\hline
\end{tabular}

${ }^{*}=$ significant difference at the level of $\mathrm{p} \leq 0.05$. 
As for the female participants classified into groups according to physical activity, a higher percentage of students with insufficient knowledge was noted in those with sufficient physical activity levels, whereas a reverse trend was observed among men (Tab. 9).

\section{Discussion}

Physical activity and proper nutrition are two most important factors that improve health and enable the development of health-oriented patterns of behaviour in university students. According to numerous studies, students usually manifest moderate or low levels of physical activity [11, 12, 13, 14]. However, PE students demonstrate higher physical activity levels $[15,16]$. The present study revealed high levels of physical activity in the majority of students.

Persons having a high level of physical activity should pay particular attention to food quantity and quality. However, the data analysis showed that the study participants did not attach too much importance to nutrition, as both first- and last-year students had low values of the HDI-10 and UDI-14 indices. Still, some differences in the frequency of consuming food items were noted. Last-year students usually consumed vegetables, poultry, groats, and pasta more often, while first-year students more frequently had food items from UDI-14, such as white bread, sweets, cold meat, or cheese. In turn, smaller differences were observed when subjects were classified with regard to physical activity levels.

Nutritional errors committed by students of different courses (including physical education) were analysed by MędrelaKuder [17]. Students often skipped breakfast, consumed too many sweets and fast foods, and had too little fish, wholemeal bread, and dairy products. Furthermore, it was noted that PE students consumed more alcohol than their peers from other courses. Similar observations were made by RomanowskaTołłoczko [12], who found that students' lifestyle was unhealthy rather than healthy. She also noted that were it not for the fact that PE students consumed the most alcohol, their lifestyle could be described as more health-oriented than that of students from other courses. When assessing the lifestyle of female PE students from Krakow, Lic, and Frankiewicz [18] observed that the participants' improper nutritional behaviours mainly stemmed from their willingness to lose weight even if there was no need to do so.

Students' improper nutritional habits may have resulted from their insufficient knowledge of the subject. Despite continual education in this field (starting with information provided by parents and then teachers at schools and university, as well as by mass media), numerous studies revealed low levels of students' knowledge regarding appropriate nutrition $[13,19$, 20]. The present study revealed sufficient knowledge levels in the majority of PE students. However, it may be noted that in the course of their studies, this knowledge improved slightly, which may be linked to attending nutrition-related courses at university. Kołłajtis-Dołowy and Boniecka [21] noted that female students who underwent nutrition-related training at university followed proper nutritional rules significantly more often than their peers who did not take any subjects associated with nutrition.

The findings of the present study as well as research results of other authors indicate that it is necessary to continue educational activities aimed at popularising principles of rational nutrition among university students.

\section{Conclusions}

The following conclusions can be drawn from the study:

1. Regardless of the level of higher education and physical activity, the students examined most often demonstrated low intensity of nutritional behaviours that were either beneficial or detrimental to health, which means that they did not consume products with a potentially beneficial influence on their health very often, but, at the same time, they limited their consumption of unhealthy products.

2. Most students demonstrated sufficient knowledge about food and nutrition; however, it was noted that university studies increased their level of knowledge in this area.

\section{Acknowledgements}

The study was carried out under research project DS. 284 at the Józef Piłsudski University of Physical Education in Warsaw, Faculty of Physical Education and Sport in Biała Podlaska. The project was financed by the Polish Ministry of Science and Higher Education.

\section{Literature}

1. Heller J.R., Sarmiento A.L. (2016). Health behaviors of culturally diverse inner-city community college students. Journal of American College Health 64(8), 651-663. DOI: 10.1080/07448481.2016.1223674.

2. Willet W.C., Stampfer M.J. (2013). Current evidence on healthy eating. Annual Review of Public Health 34, 77-95.

3. Helmer S.M., Krämer A., Mikolajczyk R.T. (2012). Healthrelated locus of control and health behaviour among university students in North Rhine Westphalia, Germany. BMC Research Notes 5, 703-710. DOI: 10.1186/1756-0500-5-703.

4. Tirodimos I., Georgouvia I., Savvala T.N., Karanika E., Noukari D. (2009). Healthy lifestyle habits among Greek university students: Differences by sex and faculty of study. Eastern Mediterranean Health Journal 15(3), 722-728.

5. Kowalska A. (2010). Nutritional habits of students from Wrocław University of Economics. Roczniki Państwowego Zakładu Higieny 61(3), 277-282. [in Polish]

6. Myszkowska-Ryciak J., Kraśniewska A., Harton A., Gajewska D. (2011). Comparison of selected nutritional behaviours of female students of the University of Physical Education and the University of Life Sciences in Warsaw. Problemy Higieny i Epidemiologii 92(4), 931-934. [in Polish]

7. Gawęcki J. (ed.) (2014). The questionnaire of nutritional attitudes and habits and the procedure of data processing. Warszawa: Komitet Nauki o Żywieniu Człowieka Polskiej Akademii Nauk. [in Polish]

8. Wądołowska L., Krusińska B. (2014). The procedure of nutritional data processing from the KomPAN questionnaire. In J. Gawęcki (ed.), The questionnaire on nutritional attitudes and habits and the procedure of data processing (pp. 34-51). Warszawa: Komitet Nauki o Żywieniu Człowieka Polskiej Akademii Nauk. [in Polish]

9. Biernat E., Stupnicki R., Gajewski A.K. (2007). International Physical Activity Questionnaire (IPAQ) - Polish version. Physical Education and Sport 51(1), 47-54.

10. Stanisz A. (2006). An intelligible course of statistics with the use of STATISTICA PL. Kraków: StatSoft Polska. [in Polish]

11. Pengpid S., Peltzer K., Kassean H.K., Tsala Tsala J.P., Sychareun V., Müller-Riemenschneider F. (2015). Physical 
inactivity and associated factors among university students in 23 low-, middle-, and high-income countries. International Journal of Public Health 60, 539-549. DOI: 10.1007/ s00038-015-0680-0.

12. Romanowska-Tołłoczko A. (2011). University students' lifestyles in the context of their health behaviours. Hygeia and Public Health 46(1), 89-93. [in Polish]

13. Szczodrowska A., Krysiak W. (2013). Analysis of selected nutritional habits and physical activity of university students in Lodz. Problemy Higieny i Epidemiologii 94(3), 518521. [in Polish]

14. Zadarko E., Barabasz Z., Nizioł E. (2011). Female students' level of physical activity on selected medical faculties against population studies. Przegląd Medyczny Uniwersytetu Rzeszowskiego i Instytutu Leków 2, 188-194.

15. Przepióra A. (2009). Free-time physical activity of firstyear students from Rzeszów University and their parents' education examined with the use of IPAQ. In J. Nowocien (ed.), Socio-educational aspects of contemporary sport and Olympism. Physical fitness of children and youth. Part 1 (pp. 221-231). Warszawa: AWF Warszawa, Akademia Olimpijska, Fundacja "Centrum Edukacji Olimpijskiej. [in Polish]
16. Walentukiewicz A., Łysak A., Wilk B. (2012). Physical activity levels in $\mathrm{PE}$ and health education students and physical activity recommendations in the prevention of lifestyle diseases. Medycyna Sportowa 2(4), 28, 129-137. [in Polish]

17. Mędrela-Kuder E. (2012). Selected nutritional habits and physical activity of PE and philology students. Polski Przegląd Nauk o Zdrowiu 3(40), 223-225. [in Polish]

18. Lic Ł., Frankiewicz M. (2007). Pro-health lifestyle elements of female students from the University of Physical Education in Krakow. Nowiny Lekarskie 76(3), 233-236. [in Polish]

19. Sień M., Zacharczuk A., Lintowska A. (2012). Nutritional behaviours of students from selected universities and the knowledge of health effects of poor nutrition. Pielegniarstwo i Zdrowie Publiczne 2(2), 113-123. [in Polish]

20. Waśkiewicz A. (2010). Quality of nutrition and the level of health knowledge in young Polish adults - the WOBASZ project. Problemy Higieny i Epidemiologii 91(2), 233-237. [in Polish]

21. Kołłajtis-Dołowy A., Boniecka I. (2007). Pro-health behaviours of a selected group of students from the Medical University of Warsaw. Roczniki Państwowego Zakładu Higieny 58(1), 273-278. [in Polish]

Submitted: February 5, 2018

Accepted: March 13, 2018 